\title{
Low-Cost Stormwater Filtration System to Improve Urban Water Quality: The Case of Addis Ababa, Ethiopia
}

\author{
Dagnachew Adugna ${ }^{1,2}{ }^{*}$, Larissa Larsen², Brook Lemma ${ }^{3}$, Geremew Sahilu ${ }^{4}$ \\ ${ }^{1}$ Ethiopian institute of Architecture, Building Construction and City Development, Addis Ababa University, Addis Ababa, \\ Ethiopia \\ ${ }^{2}$ Taubman College of Architecture and Urban Planning, University of Michigan, Ann Arbor, Michigan, USA \\ ${ }^{3}$ College of Natural Science, Addis Ababa University, Addis Ababa, Ethiopia \\ ${ }^{4}$ Institute of Water Resources, Addis Ababa University, Addis Ababa, Ethiopia \\ Email: ^dagnachew2@gmail.com
}

How to cite this paper: Adugna, D., Larsen, L., Lemma, B. and Sahilu, G. (2017) Low-Cost Stormwater Filtration System to Improve Urban Water Quality: The Case of Addis Ababa, Ethiopia. Journal of Water Resource and Protection, 9, 692-705.

https://doi.org/10.4236/jwarp.2017.96046

Received: February 25, 2017

Accepted: May 24, 2017

Published: May 27, 2017

Copyright (C) 2017 by authors and Scientific Research Publishing Inc. This work is licensed under the Creative Commons Attribution International License (CC BY 4.0).

http://creativecommons.org/licenses/by/4.0/

\begin{abstract}
Urbanization in developing countries often negatively impacts water resources by polluting surface waters. Addis Ababa, Ethiopia, is currently experiencing rapid urbanization accompanied by significant water shortages, unmanaged stormwater, and increasing river water pollution. To supplement the need for non-potable water and address stormwater runoff pollution, we constructed a low cost stormwater filtration system. The filtration system is comprised of a sedimentation area followed by three gravel grain sizes arranged horizontally from coarse to medium to fine filter media. We compared the quality of pretreatment water with post-treatment water by measuring physicochemical parameters, heavy metals and nutrients. We found that the filtration system reduced turbidity by $87 \%$, TSS by $80 \%$, Cu by $87 \%$ and $\mathrm{Zn}$ by $90 \%$. Further, it positively increased the concentration of DO by $42 \%$. However, the filtration system did not remove nitrates and nitrites. Implementing this system at outfalls in the rapidly expanding condominium housing areas can increase residents' supply of non-potable water and reduce the amount of polluted stormwater entering nearby streams and rivers.
\end{abstract}

\section{Keywords}

Low Cost, Stormwater, Filtration, Addis Ababa, Water Quality, Performance Test

\section{Introduction}

Urbanization in developing countries often negatively impacts water resources 
by polluting surface waters [1] [2] and decreasing infiltration to recharge aquifers [3] [4]. Simultaneously, water demand increases with population growth and per capita consumption rises with increasing standards of living. Addis Ababa, which is the capital of Ethiopia and the site of many international organizations, is currently experiencing rapid urbanization [5] [6]. Since 2007 when the population was 2.7 million [7], it has expanded to an estimated 4 million. For new residents, access to water as well as housing is two significant problems.

In an effort to address Addis Ababa's housing shortage, the city administration is constructing an extensive number of multi-story, multi-family condominium projects. According to the Addis Ababa Housing Construction and Development Bureau (2014), these multistory condominiums, are located on more than 134 sites throughout the city and are projected to house 1.3 million people upon completion [6]. One of the problems linked with these new developments is a water shortage due to the imbalance between the available water supply sources (such as limited water supply sources and insufficient water infrastructure) and the growing population (the annual rate of population growth is $2.8 \%$ ) [8].

The natural distribution of rainfall is another challenge to the provision of water for Addis Ababa residents. While the city receives an average annual rainfall of $1057 \mathrm{~mm}$ [9], 75\% falls during a four-month rainy season. Due to the erratic nature of the rainfall, improving water supplies would require huge reservoirs to harvest rain water for later use. These are unaffordable and practically impossible. Little attention is given to stormwater management as a resource and most stormwater is directly discharged into rivers reducing river water quality [10]. The rivers are highly polluted year round and many city residents consider the rivers as sewer lines [11]. Thus, providing a low cost stormwater filtration system could provide water for non-potable uses at the new condominium developments and reduce the amount of polluted stormwater reaching the rivers. Moreover, the filtration system addressed residents' stated concerns that standing water impeded children's play in the common areas.

Sustainable stormwater filtration systems are generally categorized either as coarse or fine filtration systems. Coarse media stormwater filtration is efficient for larger pollutant removal, but it is not effective in removing dissolved pollutants [12]. In addition, coarse media filtration is more likely to clog due to the migration of fine sediments and compaction of the media [13]. Conversely, fine filter media may provide for better removal of pollutants through mechanisms that include fine filtration, sorption, ionic adhesion, and precipitation [14] [15]. Recently sustainable stormwater management systems are increasingly used in both the United States and Australia [16], although there is currently limited data evaluating their water quality impacts [17] [18].

In addition, sand filtration systems are also categorized as either slow or rapid sand filters. In general, the sand filtration systems work vertically at various depths and they are generally found to be more effective at greater depths. Slow sand filters have a grain size of 0.15 to $0.35 \mathrm{~mm}$ and are used as a secondary treatment to reduce pathogen concentrations. Slow sand filtration is used to 
produce drinking water-the size of the filtration system is determined based on the required flow rate [19]. Slow sand filter is a biological process which reduces bacteria from 90\% - 99\% without chemicals [19]. However, slow sand filtration requires low turbidity levels to work efficiently and filters water at a slow, constant rate so that the biological processes can occur [19]. In Gaza, a vertical slow sand filtration system was tested for fecal coliform and suspended solid to investigate the removal efficiency of the system at different filter depth. Using a 203 $\mathrm{mm}$ (or 8 inch) cylindrical PVC-U pipe, the slow sand filter removed fecal coliform at a depth of $150 \mathrm{~cm}$ [20].

Rapid sand filters use sand that varies from 0.4 to $12.0 \mathrm{~mm}$ in grain size and they are used for primary treatment [21]. Rapid sand filtration alone is not as effective for producing drinking water as slow sand filtration due to the fact that the biological systems are relatively less effective [19]. According to Zaman et al. [19], rapid sand filtration is suitable for large urban areas where land is scarce. Conversely slow filtration is suitable to areas where land scarcity is not a problem as it requires a larger surface area to filter the same amount of water.

Gravel is the other commonly used filter media to treat polluted water by the formation of biofilm. The biofilm is a gelatinous layer consisting of bacteria, algae, protozoa and other aquatic insect larvae that develops after 10 to 20 days of operation and degrades some of the organic components. Further, the filter materials remove pollutants by adsorption, sedimentation, physical and mechanical straining [22]. Moreover, in a vermifiltration system, gravel ranging in grain size from 10 to $40 \mathrm{~mm}$ in combination with sawdust was used to filter grey wastewater. The average removal efficiency of the system for TSS was found to be 98\% [23].

To correct some of the identified drawbacks of the coarse media filtration and the sand filtration systems, the present study combined three gravel grain sizes (coarse, medium and fine gravels). To maintain separation of the three gravel areas, we added layers of wire mesh. Importantly to reduce the possibility of clogging, a sedimentation pond was created nearest the inlet to trap sediments before it entered the filtration system.

This study focuses on a horizontal filtration system where water passes through the three grain sizes-from the coarse to the fine gravel. We selected this horizontal arrangement, as opposed to a vertical system, so the water could flow smoothly at shallow depths without mechanical pumping. We call this a low cost stormwater filtration system because it relies on locally available materials, is relatively low-cost, is simple to construct and requires no pumping. This system is appropriate for the context of Addis Ababa because it would help reduce water shortages in the condominium housing areas and reduce the contribution of polluted stormwater to the rivers. Municipalities or community groups could implement this low-cost stormwater filtration system at outfalls along with installing new drains and retrofitting the existing outfalls.

The specific objectives of this study are to:

- Characterize pre treatment stormwater quality at the condominium site,

- Develop low-cost stormwater filtration system and estimate the filtration ca- 
pacity of the system,

- Test the performance of the low-cost stormwater filtration system in reducing pollutants.

\section{Materials and Methodology}

\subsection{Study Area}

The study area is located at the "Biruh tesfa" compound in Jemo No. 1 condominium in a southwestern part of Addis Ababa. There are 1264 people who live in "Biruh tesfa". The "Biruh tesfa" community gave permission for the construction and testing of this filtration system (Figure 1). In addition, there was a commitment from the community representatives to connect the filtration system with storage tanks to use the filtered water for non-drinking purposes (e.g. car washing, urban agriculture within the "Biruh tesfa" compound).

\subsection{Materials and Methods}

Stormwater at the "Biruh tesfa" compound was collected at a manhole where stormwater from a rooftop, local streets, and parking lots combined. The manhole is connected to our filtration system by underground PVC pipe. Based on the volume of the stormwater from the rooftop, local streets, and parking lots, we selected a $110 \mathrm{~mm}$ PVC pipe stormwater (Figure 2).

On site, a 2.22 meter by 1.22 meter rectangular brick masonry box was constructed in the ground at a depth of 0.60 meter (Figure 3 ). The box for the filtration system was made based on the volume of stormwater which can be generated from the rooftop, local street and parking lots. The filtration bed was made from concrete on top of compacted stones. The walls were plastered with mortar to prevent leakage and/or entrance of water from outside via the brick joints. To

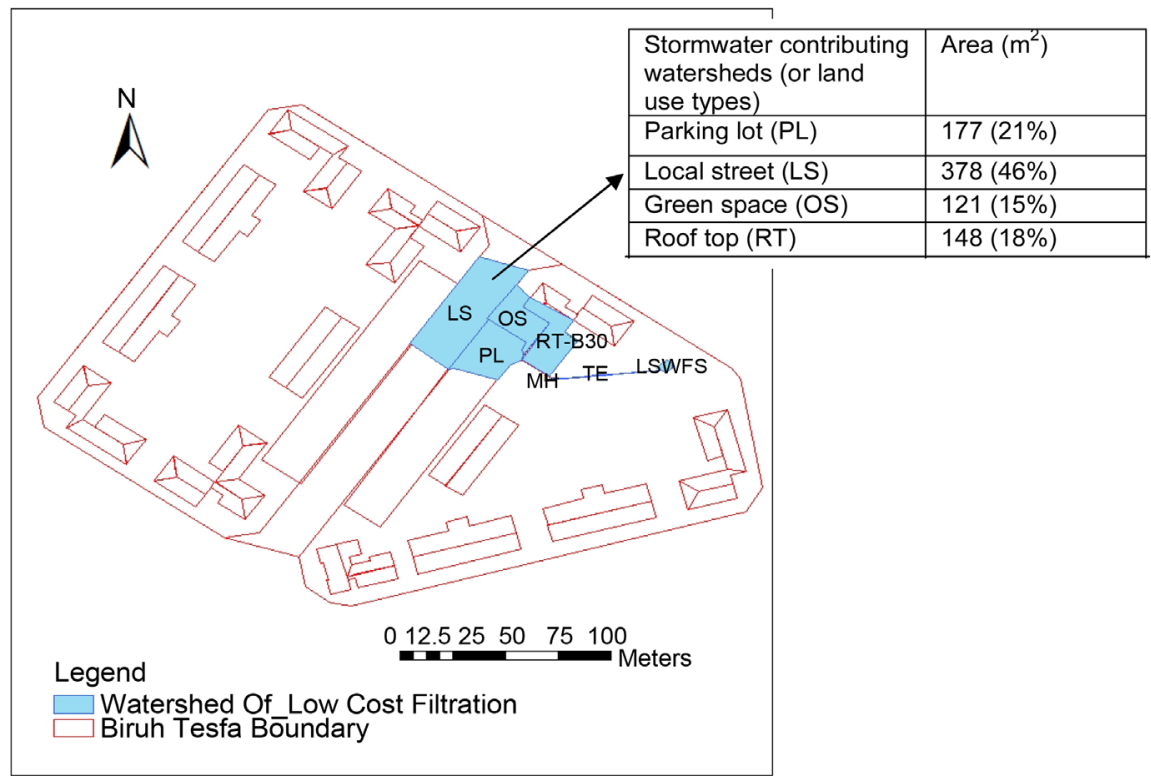

Figure 1. The condominium housing area, filtration system, and distribution of area land uses. 


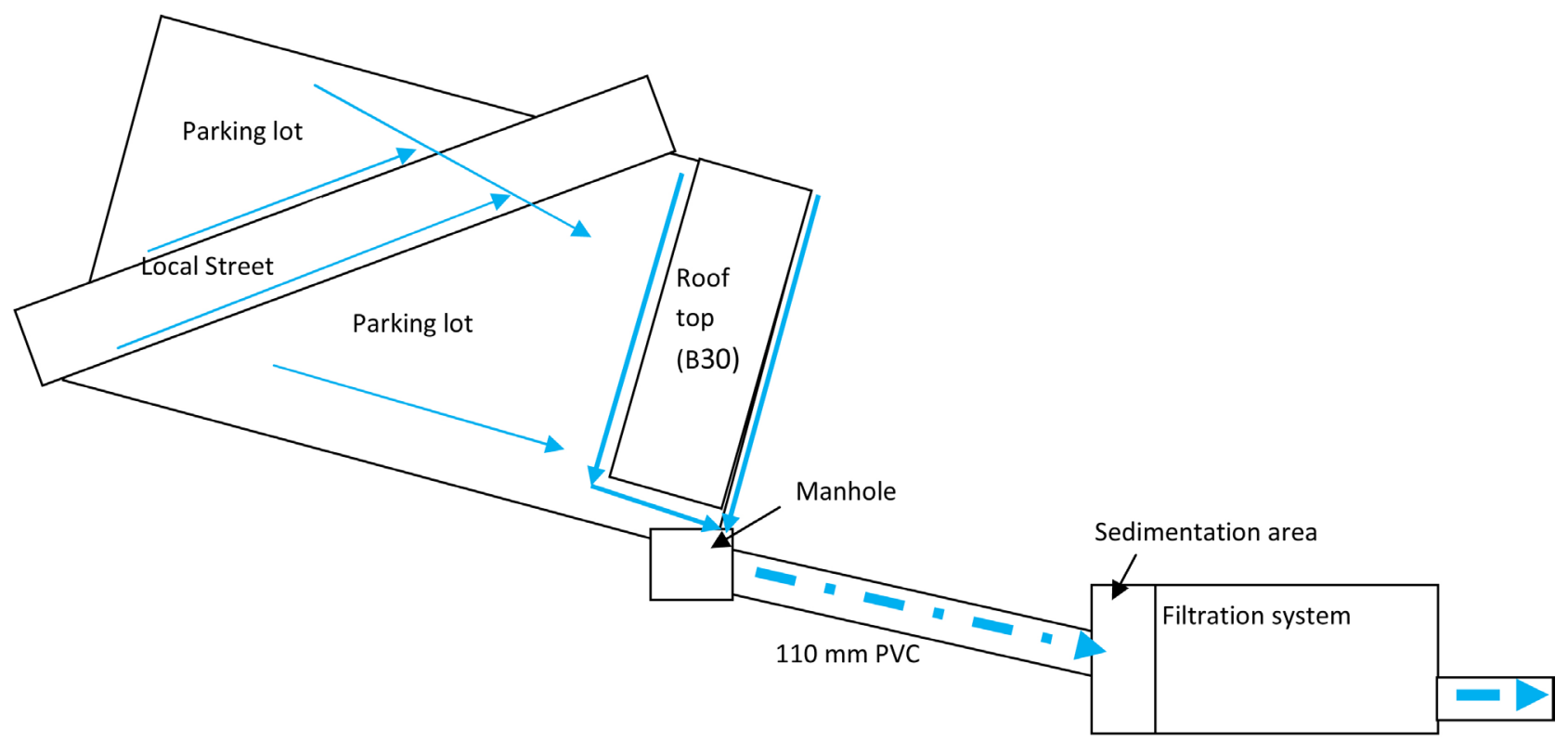

Figure 2. Schematic presentation of the filtration system with the contributing sub-watersheds that drain into the system (B30 stands for Block No. 30 apartment).

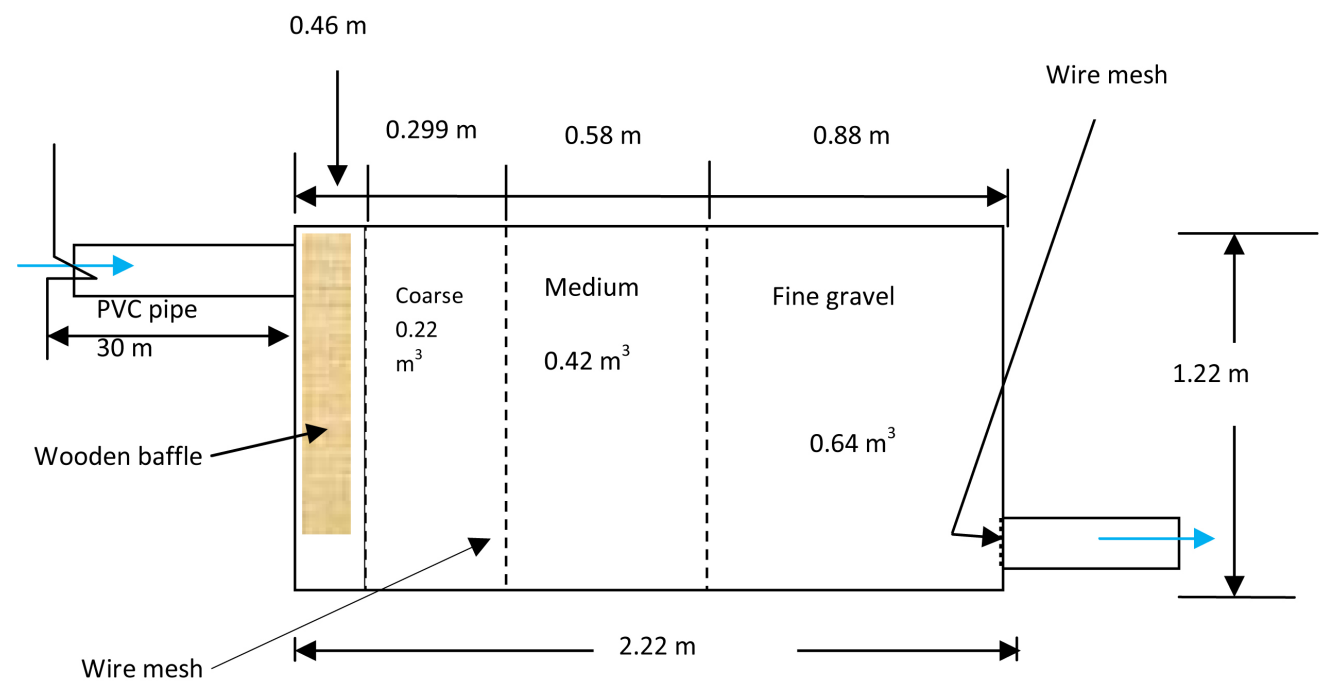

Figure 3. The schematic presentation of the elements of the low-cost stormwater filtration system with their dimensions and volumetric capacity.

prevent the entrance of rainwater from the top, after the three filters media were in place, geo-synthetic material was laid on the top. The top of the filtration system was then covered with soil except for the area over the sedimentation pond that was covered by a reinforced concrete slab to permit maintenance. Within the rectangular masonry box, there are four different compartments. The sedimentation area at the inlet of the system traps is created by a wood baffle. This area permits sediments and some soluble pollutants to settle before water then enter into the filtration system.

After the sedimentation area, the next three compartments are filled with coarse $(30-40 \mathrm{~mm})$, medium $(20-30 \mathrm{~mm})$ and fine $(10-20 \mathrm{~mm})$ gravel respec- 
tively. Small holes were uniformly drilled at a depth of 25 centimeters from the top on the common wall between the sedimentation area and the filtration system (Figure 4). The length of the filter with the finest gravel was $50 \%$ of the total length of the filtration system and the medium was about $33 \%$. The remaining $17 \%$ of the total length of the filtration system was the coarse gravel. The area with the finest gravel is largest due to its smaller hydraulic conductivity and relative importance in filtering the stormwater.

\subsection{Stormwater Samples Collection for Performance Test}

To evaluate the filtration system's performance, stormwater samples were collected before and after the filtration system. Pre treatment samples were taken at the manhole. Post treatment samples were taken after the stormwater passed through the filtration system. For reliability, we collected three sets of samples within a rainy season (between July and August), more than 10 days after construction (to let the biofilms develop).

The pre and post-treatment water samples were tested for levels of physicochemical parameters $(\mathrm{pH}, \mathrm{EC}$, Turbidity and $\mathrm{DO})$, nutrients $\left(\mathrm{NO}_{2}-\mathrm{N}, \mathrm{NO}_{3}-\mathrm{N}\right.$, $\mathrm{NH}_{3}-\mathrm{N}$ and $\left.\mathrm{PO}_{4}-\mathrm{P}\right)$ and heavy metals $(\mathrm{Cu}, \mathrm{Cr}, \mathrm{Pb}$ and $\mathrm{Zn})$.

\subsection{Stormwater Samples Transportation}

The stormwater samples were collected with a plastic container (20 liters in volume) pre and post treatment in the low-cost stormwater filtration system immediately after rain fall and measured in-situ for $\mathrm{pH}, \mathrm{DO}(\mathrm{mg} / \mathrm{l}), \mathrm{EC}(\mu \mathrm{s} / \mathrm{cm})$ and Turbidity (NTU). The other stormwater samples for $\mathrm{NO}_{2}-\mathrm{N}, \mathrm{NO}_{3}-\mathrm{N}$, $\mathrm{NH}_{3}-\mathrm{N}, \mathrm{PO}_{4}-\mathrm{P}, \mathrm{Cu}, \mathrm{Pb}, \mathrm{Zn}$, and $\mathrm{Cr}$ analysis were collected at same time at the same sampling point with plastic bottles rinsed with distilled water $(1000 \mathrm{ml}$ in volume) and then transported within two hours for laboratory analysis.

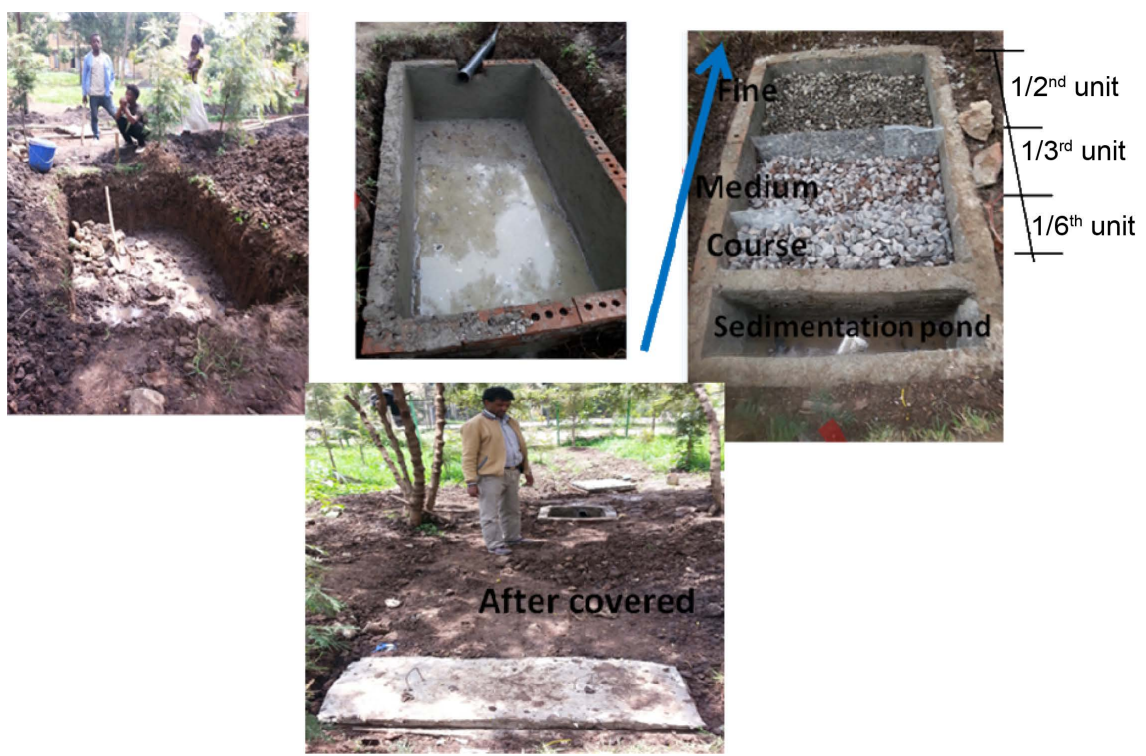

Figure 4. The low-cost stormwater filtration system from excavation to filling the system with filtration media (top) to making the system ready for performance test (bottom). 


\subsection{Stormwater Samples Measurement}

The physicochemical parameters (DO, $\mathrm{pH}, \mathrm{EC}$ and Turbidity) were measured using standard methods (APHA, 1998). The DO probe (LDO 10105, Model USPAT 6912050) and the Conductivity probe (CDC 40105) were mounted on the multi-meter (Hach-Model-HQ40d multi-parameter digital meter) which measures $\mathrm{DO}$ and $\mathrm{pH}$, and $\mathrm{EC}$ respectively. The turbidity was measured using the portable turbidity meter (OAKTON T-100 Model).

The concentration of $\mathrm{NO}_{2}-\mathrm{N}, \mathrm{NO}_{3}-\mathrm{N}, \mathrm{NH}_{3}-\mathrm{N}$ and $\mathrm{PO}_{4}-\mathrm{P}$ were analyzed at the lab using spectrophotometer (JENWAY $6405 \mathrm{UV} / \mathrm{Vis}$ ) following standard methods (APHA, 1995).

The heavy metals including $\mathrm{Cr}, \mathrm{Cu}, \mathrm{Mn}$, and $\mathrm{Zn}$ were analyzed using Bicin Chonimate, Diphenyl carbohydride, Periodate oxidation and Zincon ( $\mathrm{HACH}$, Atomic Absorption Spectrometer) methods respectively.

\subsection{Softwares Used to Delineate the Land Uses Draining in to the Filtration System}

ArcGIS was used to delineate the contributing sub-watersheds (or land uses) that drain stormwater into the filtration system and to calculate the area of each contributing sub-watershed following ESRI's standard method. Furthermore, Microsoft excel was employed to analyze the in-situ and laboratory data of stormwater including the means and percentage removal efficiency of the filtration system.

\section{Results}

\subsection{The Low-Cost Stormwater Filtration System and Its Filtering Capacity}

Based on Figure 2, the volume of the filtration system and volume of stormwater diverted from upstream contributing land uses in to the filtration system was computed as follows:

Volume of stormwater diverted from the rooftop (Rt), Local street (Ls), Parking lots $(\mathrm{Pl})$ and green spaces (Gs) in to the filtration system:

= stormwater from (rooftops + local streets + parking lots + green spaces);

$=$ Area of contributing land use $\times$ Runoff coefficient $\times$ Daily rainfall;

$=(\mathrm{A}$ of Rt $\times \mathrm{C} \times \mathrm{R})+(\mathrm{A}$ of $\mathrm{Ls} \times \mathrm{R})+(\mathrm{A}$ of $\mathrm{Pl} \times \mathrm{C} \times \mathrm{R})+(\mathrm{A}$ of $\mathrm{Gs} \times \mathrm{C} \times \mathrm{R})$;

$=\left(148 \mathrm{~m}^{2} \times 0.85 \times 31.4 \mathrm{~mm} /\right.$ day $)+\left(378 \mathrm{~m}^{2} \times 0.5 \times 31.4 \mathrm{~mm} /\right.$ day $)+\left(177 \mathrm{~m}^{2} \times\right.$

$0.4 \times 31.4 \mathrm{~mm} /$ day $)+\left(121 \mathrm{~m}^{2} \times 0.2 \times 31.4 \mathrm{~mm} /\right.$ day $)$;

$=12,870$ liters per day or 536 liters per hour or 8.9 liters per minute.

According to the volume of stormwater which can be generated from the contributing land uses, the volume and capacity of the filtration system was estimated.

Volume of filtration system $=$ Volume of the $($ course + medium + fine $)$ filter ing media:

$=(0.229 \mathrm{~m} \times 1.22 \mathrm{~m} \times 0.6 \mathrm{~m})+(0.58 \mathrm{~m} \times 1.22 \mathrm{~m} \times 0.60 \mathrm{~m})+(0.86 \mathrm{~m} \times 1.22$ $\mathrm{m} \times 0.60 \mathrm{~m})$; 


$$
=1.28 \mathrm{~m}^{3} \text {. }
$$

The PVC pipe transports $1.14 \mathrm{~m}^{3}\left(\pi \times \mathrm{r}^{2} \times 30 \mathrm{~m}\right)$ of stormwater once per its entire length $(30 \mathrm{~m})$ showing that with a free board of nearly $10 \%$ the filtration system $\left(1.28 \mathrm{~m}^{3}\right.$ capacity) has the ability to hold all the stormwater that passes through the PVC pipe. Further, stormwater from the common points of the contributing watersheds (i.e. at the manhole) to the filtration system were reached in 70 seconds. Thus, 10.42 liters $\left\{\left(12.8 \mathrm{~m}^{3} \times 70 \mathrm{sec}\right) \div(24 \mathrm{hr} \times 3600\right.$ $\mathrm{sec} / \mathrm{hr}$ ) $\}$ of stormwater could be filtered (or treated) per 70 seconds revealing that 0.15 liters (10.42 liters $\div 70 \mathrm{sec}$ ) of stormwater could be filtered per second by the filtration system.

In the future, we hope that water storage tanks will be connected to the outlet of the filtration system and local residents can use the filtered water for activities such as car washing and urban agriculture.

\subsection{Pre Treatment Stormwater Quality}

The concentration of stormwater pollutants and physicochemical parameters found in-situ and with laboratory measurements is reported in Table 1.

\subsection{Performance of the Low-Cost Stormwater Filtration System}

The performance of the filtration system was tested for physicochemical parameters, heavy metals, total suspended solids and nutrients (Tables 2-4). The results of the present study showed that, with the exception of the nutrients, quality of the stormwater had notably improved.

Physical observation (as presented in Figure 5) showed that the filtration system in clarity after filtration.

Table 1. The pre-treatment concentration of stormwater pollutants at "Biruh tesfa" compound.

\begin{tabular}{|c|c|c|c|c|c|}
\hline \multirow{2}{*}{\multicolumn{2}{|c|}{$\begin{array}{l}\text { Stormwater pollutants and } \\
\text { physicochemical parameters }\end{array}$}} & \multicolumn{3}{|c|}{ Replications } & \multirow{3}{*}{$\begin{array}{c}\begin{array}{c}\text { Mean } \\
\text { value }\end{array} \\
4.32\end{array}$} \\
\hline & & \multirow{2}{*}{$\begin{array}{c}1 \\
5.15\end{array}$} & \multirow{2}{*}{2.56} & \multirow{2}{*}{$\begin{array}{c}3 \\
5.26\end{array}$} & \\
\hline \multirow{4}{*}{$\begin{array}{l}\text { Physicochemical } \\
\text { parameters }\end{array}$} & $\mathrm{DO}(\mathrm{mg} / \mathrm{l})$ & & & & \\
\hline & Turbidity (NTU) & 777 & 675.3 & 454 & 635.43 \\
\hline & $\mathrm{EC}(\mu \mathrm{s} / \mathrm{cm})$ & 44.9 & 41.7 & 63.4 & 50.00 \\
\hline & $\mathrm{pH}$ & 8.58 & 7.96 & 8.13 & 8.22 \\
\hline \multirow{4}{*}{ Heavy metals } & $\mathrm{Cu}(\mathrm{mg} / \mathrm{l})$ & 0.12 & 0.08 & 0.03 & 0.08 \\
\hline & $\mathrm{Pb}(\mathrm{mg} / \mathrm{l})$ & $\mathrm{BDL}$ & $\mathrm{BDL}$ & $\mathrm{BDL}$ & - \\
\hline & $\mathrm{Zn}(\mathrm{mg} / \mathrm{l})$ & 2.30 & 3.72 & 5.06 & 3.69 \\
\hline & $\mathrm{Cr}(\mathrm{mg} / \mathrm{l})$ & $\mathrm{BDL}$ & $\mathrm{BDL}$ & $\mathrm{BDL}$ & - \\
\hline \multirow{4}{*}{ Nutrients } & $\mathrm{NO}_{2}-\mathrm{N}(\mathrm{mg} / \mathrm{l})$ & 0.538 & 4.15 & 0.167 & 1.62 \\
\hline & $\mathrm{NO}_{3}-\mathrm{N}(\mathrm{mg} / \mathrm{l})$ & 0.179 & 0.094 & 0.393 & 0.074 \\
\hline & $\mathrm{NH}_{3}-\mathrm{N}(\mathrm{mg} / \mathrm{l})$ & 0.422 & 0.523 & 0.074 & 0.114 \\
\hline & $\mathrm{PO}_{4}-\mathrm{P}(\mathrm{mg} / \mathrm{l})$ & 0.374 & 0.196 & 0.0178 & 0.065 \\
\hline
\end{tabular}


Table 2. Physicochemical water quality parameters.

\begin{tabular}{|c|c|c|c|c|c|c|c|c|c|}
\hline & \multicolumn{6}{|c|}{ Replication No. } & \multirow{2}{*}{\multicolumn{2}{|c|}{ Mean }} & \multirow{3}{*}{$\begin{array}{l}\% \text { mean } \\
\text { removal }\end{array}$} \\
\hline & \multicolumn{2}{|c|}{1} & \multicolumn{2}{|c|}{2} & \multicolumn{2}{|c|}{3} & & & \\
\hline & Before & After & Before & After & Before & After & Before & After & \\
\hline $\begin{array}{c}\text { Turbidity } \\
\text { (NTU) }\end{array}$ & 777 & 123.33 & 675.3 & 454 & 454 & 79.10 & 635.43 & 84.04 & $-87 \%$ \\
\hline $\mathrm{EC}(\mu \mathrm{s} / \mathrm{cm})$ & 44.9 & 37.87 & 41.7 & 35.60 & 63.4 & 54.90 & 50.00 & 42.79 & $-14 \%$ \\
\hline $\mathrm{pH}$ & 8.58 & 7.88 & 7.96 & 7.88 & 8.13 & 8.00 & 8.22 & 7.92 & $4 \%$ \\
\hline DO (mg/l) & 5.15 & 6.2 & 2.56 & 4.7 & 5.26 & 7.5 & 4.32 & 6.15 & $+42 \%$ \\
\hline $\begin{array}{c}\text { Total } \\
\text { suspended } \\
\text { solids }(\mathrm{mg} / \mathrm{l})\end{array}$ & 2777.10 & 92.80 & 1040 & 415 & 1535 & 580 & 1784.033 & 362.60 & $-80 \%$ \\
\hline
\end{tabular}

Table 3. Heavy metals.

\begin{tabular}{|c|c|c|c|c|c|c|c|c|c|}
\hline & \multicolumn{6}{|c|}{ Replication No. } & \multirow{2}{*}{\multicolumn{2}{|c|}{ Mean }} & \multirow{3}{*}{$\begin{array}{l}\% \text { mean } \\
\text { removal }\end{array}$} \\
\hline & \multicolumn{2}{|l|}{1} & \multicolumn{2}{|c|}{2} & \multicolumn{2}{|c|}{3} & & & \\
\hline & Before & After & Before & After & Before & After & before & After & \\
\hline $\mathrm{Cu}(\mathrm{mg} / \mathrm{l})$ & 0.12 & 0.02 & 0.08 & 0.00 & 0.03 & 0.01 & 0.0767 & 0.01 & $-87 \%$ \\
\hline $\mathrm{Zn}(\mathrm{mg} / \mathrm{l})$ & 2.30 & 0.20 & 3.72 & 0.21 & 5.06 & 0.73 & 3.69 & 0.38 & $-90 \%$ \\
\hline $\mathrm{Pb}(\mathrm{mg} / \mathrm{l})$ & $\begin{array}{c}\text { Below } \\
\text { detection } \\
\text { limit (BDL) }\end{array}$ & BDL & $\mathrm{BDL}$ & $\mathrm{BDL}$ & $\mathrm{BDL}$ & BDL & $\mathrm{BDL}$ & $\mathrm{BDL}$ & - \\
\hline $\mathrm{Cr}(\mathrm{mg} / \mathrm{l})$ & BDL & BDL & BDL & BDL & $\mathrm{BDL}$ & $\mathrm{BDL}$ & BDL & BDL & - \\
\hline
\end{tabular}

Table 4. Nutrients.

\begin{tabular}{|c|c|c|c|c|c|c|c|c|c|}
\hline & \multicolumn{6}{|c|}{ Replication No. } & \multirow{2}{*}{\multicolumn{2}{|c|}{ Mean }} & \multirow{3}{*}{$\begin{array}{l}\% \text { mean } \\
\text { removal }\end{array}$} \\
\hline & \multicolumn{2}{|c|}{1} & \multicolumn{2}{|c|}{2} & \multicolumn{2}{|c|}{3} & & & \\
\hline & Before & After & Before & After & Before & After & before & After & \\
\hline $\begin{array}{c}\mathrm{NH}_{3}^{+}-\mathrm{N} \\
(\mathrm{mg} / \mathrm{l})\end{array}$ & 0.422 & 0.069 & 0.523 & 0.18 & 0.074 & 0.378 & 0.340 & 0.209 & $-38 \%$ \\
\hline $\begin{array}{l}\mathrm{PO}_{4}-\mathrm{P} \\
(\mathrm{mg} / \mathrm{l})\end{array}$ & 0.374 & 0.168 & 0.196 & 0.223 & 0.0178 & 0.045 & 0.196 & 0.145 & $-26 \%$ \\
\hline $\begin{array}{c}\mathrm{NO}_{2}-\mathrm{N} \\
(\mathrm{mg} / \mathrm{l})\end{array}$ & 0.538 & 3.086 & 4.154 & 0.374 & 1.675 & 19.22 & 2.122 & 7.560 & +356 \\
\hline $\begin{array}{c}\mathrm{NO}_{3}-\mathrm{N} \\
(\mathrm{mg} / \mathrm{l})\end{array}$ & 0.179 & 3.299 & 0.094 & 0.607 & 0.383 & 0.393 & 0.219 & 1.433 & +654 \\
\hline
\end{tabular}

\section{Discussion}

The present study was limited to stormwater filtration as the entire condominium site where all the sanitation systems (e.g. toilets, showers, kitchens) are connected into a separate sewer system. 


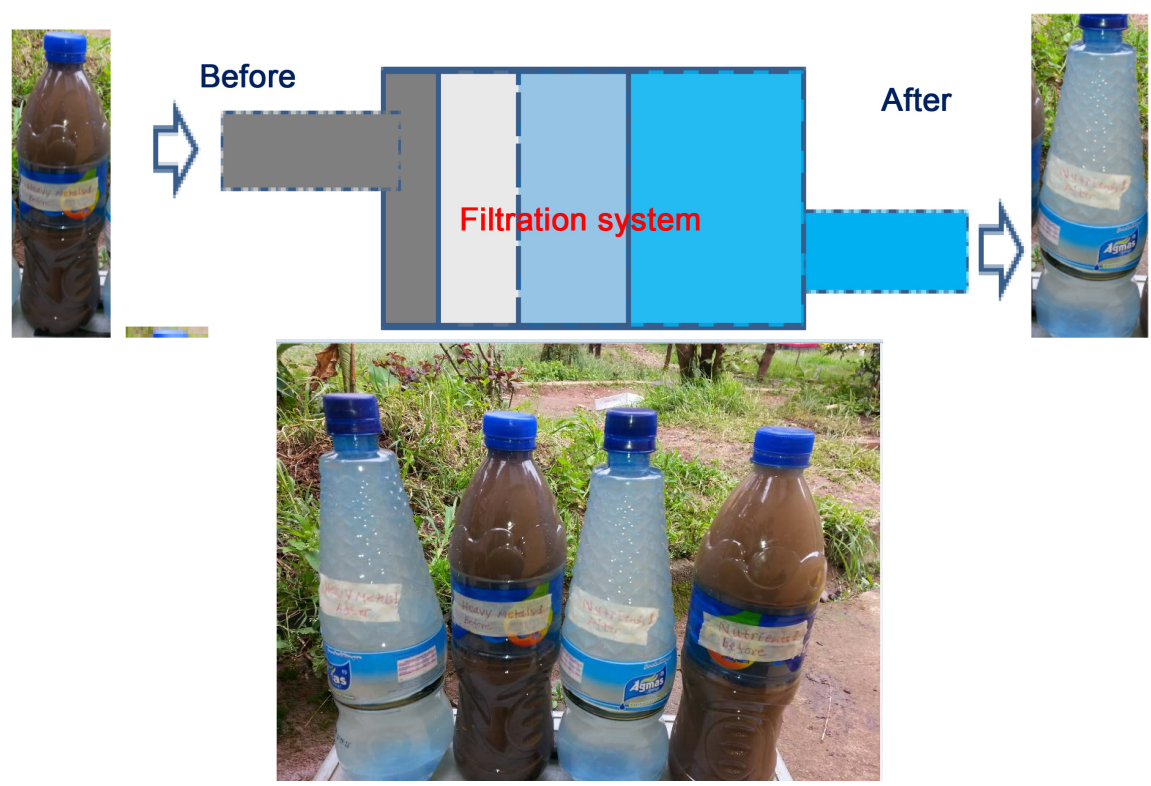

Figure 5. A physical comparison of the performance of the filtration system before and after filtration shows the improvement in the water quality.

\subsection{Characterization of Stormwater Pollutants and Physicochemical Parameters}

In Addis Ababa, Ethiopia, the absence of stormwater water quality data has hindered research. Therefore, the pretreatment stormwater pollutant data may serve as a baseline for further investigations. The data showed that stormwater pollutants common in urban areas [24] [25] [26] were also found at the condominium housing site.

\subsection{Building a Low-Cost Stormwater Filtration System}

As in many urban areas, stormwater management is a problem in Addis Ababa, Ethiopia [27] [28]. This stormwater filtration system was built to investigate a low-cost, on-site approach that provide residents with additional water and reduce stormwater pollutants from entering the river. In the short term (before city-wide structures are put in place), low-cost stormwater filtration system such as this one can be installed at outfalls in existing or newly constructed drains. This system costs approximately $\$ 1400$ USD.

\subsection{Performance of the Low-Cost Stormwater Filtration System}

Based on a comparison of pre and post-treatment water samples, the filtration system removed turbidity by $87 \%$, decreased conductivity by $14 \%$ and increased the desirable dissolved oxygen by $42 \%$. The filtration system also removed the detected heavy metals of $\mathrm{Cu}$ and $\mathrm{Zn}$ by more than $85 \%$. This is promising when compared with the heavy metal reduction achieved by other stormwater treatment technologies such as wetlands, infiltration trenches, retention ponds [29] [30]. The performance test provided evidence for the effectiveness of the system at outfalls (refer Figure 6) in areas of the city where no pathogens are not expected 


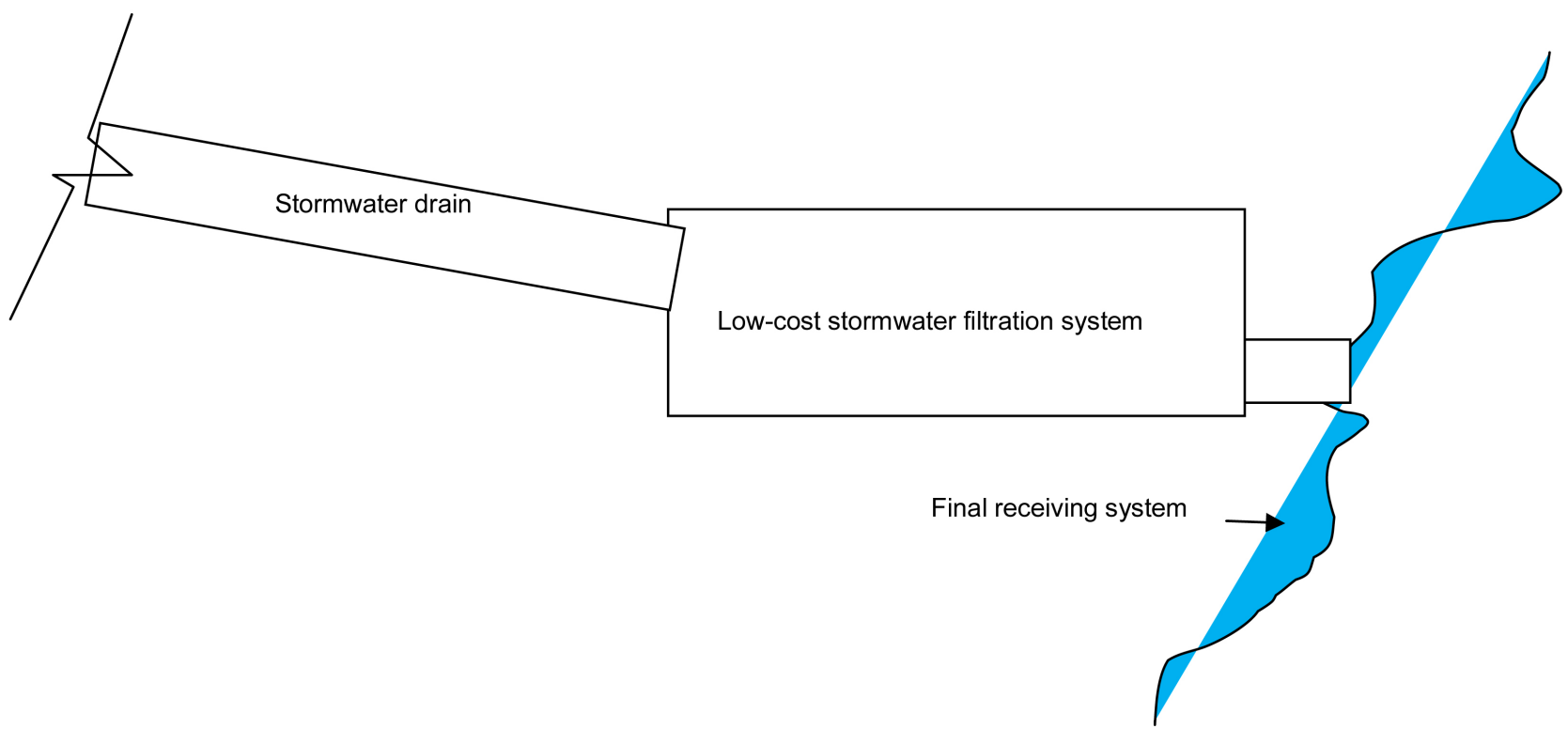

Figure 6. Installing the low-cost stormwater filtration system as outfall.

due to the presence of sewer systems (e.g. condominiums, industries, universities). This implies that if Addis Ababa is going to install the present technology at outfalls the rivers water quality will be significantly improved.

Such promising performances may be due to adsorption [31] [32] and the formation of biofilms (a thin layer of cells of microorganisms such as bacteria, and fungus) on the surfaces of the gravel (Headley \& Tanner, 2012 and Wong et al., 1999). In addition, the sedimentation area combined with adsorption and biofilms might have increased the performance of the filtration system by settling the dissolved pollutants before they get in to the filtration system. The findings of Jellison et al. (2000) showed that biofilm can be developed $10-20$ days after construction-which is consistent with the present study as samples were taken from the filtration system after 10 days.

The present study cannot be compared with sand filtration systems conducted by various researchers (e.g. Zaman et al., 2014; Nassar \& Hajjaj, 2013 and Rowe \& Abdel-Majid, 1995) as the grain size of sand filtration system varied significantly. In addition, our system involved three gravel grain sizes in a horizontal arrangement. Conversely, studies conducted by Rowe \& Abdel-Majid (1995), Nassar \& Hajjaj (2013) and Zamana et al. (2014) used different the filter media (i.e. the sands) and were vertically arranged.

\section{Conclusion}

In Addis Ababa, Ethiopia, stormwater runoff carries pollutants that impair river water quality. Thus, to supplement residents' need for non-potable water supplies and to improve river water quality, we constructed a low cost stormwater filtration system and tested its effectiveness in July through August 2016 (during the Ethiopian rainy season) by comparing water samples based on levels of physicochemical parameters, heavy metals and nutrients. The stormwater was col- 
lected from the rooftops, a local street, and parking lots. Our system used three gravel grain sizes (coarse, medium and fine) arranged horizontally from coarse to medium to fine. Based on water sample testing, our filtration system removed turbidity, total suspended solids, and heavy metals by more than $80 \%$. Further, it increased the concentration of dissolved oxygen by $42 \%$. However, our filtration system was not effective at lowering nitrates and nitrites levels. It is our hope that the filtered stormwater will eventually be connected to an underground storage tank at the "Biruh tesfa" condominium housing site. We will continue to monitor the water quality and we hope this low-cost filtration system will serve as a community asset that produces water quality improvements and assists residents in their daily tasks.

\section{References}

[1] Ouyang, T., Zhu, Z. and Kuang, Y. (2006) Assessing Impact of Urbanization on River Water Quality in the Pearl River Delta Economic Zone, China. Environmental Monitoring and Assessment, 120, 313-325. https://doi.org/10.1007/s10661-005-9064-x

[2] Alemayehu, T. (2001) The Impact of Uncontrolled Waste Disposal on Surface Water Quality in Addis Ababa, Ethiopia. Ethiopian Journal of Science, 24, 93-104.

[3] Pitt, R., Chen, S.E., Clark, S.E., Swenson, J. and Ong, C.K. (2008) Compaction's Impacts on Urban Storm-Water Infiltration. Journal of Irrigation and Drainage Engineering, 134, 652-658. https://doi.org/10.1061/(ASCE)0733-9437(2008)134:5(652)

[4] Holman-Dodds, J.K., Bradley, A.A. and Potter, K.W. (2007) Evaluation of Hydrologic Benefits of Infiltration Based Urban Storm Water Management. Journal of the American Water Resources Association, 39, 205-215. https://doi.org/10.1111/j.1752-1688.2003.tb01572.x

[5] Mazhindu, E., Gumbo, T. and Gondo, T. (2010) Living with Environmental Health Risks-The Case of Addis Ababa. Ecohydrology \& Hydrobiology, 10, 281-286. https://doi.org/10.2478/v10104-011-0026-3

[6] Haregewoin, Y.M. (2007) Integrated Housing Development Programs for Urban Poverty Alleviation and Sustainable Urbanization: The Case of Addis Ababa. ENHR International Conference on Sustainable Urban Areas, Institute for Housing and Urban Development Studies (IHS), Rotterdam.

[7] CSA (2008) Summary and Statistical Report of the 2007 Population and Housing Census. Addis Ababa, Ethiopia.

[8] AAWSA (2011) Business Plan from 2011-2020, Final Report. Addis Ababa, Ethiopia.

[9] National Metrology Agency (2016) Rainfall data of Addis Ababa from 2000 to 2015. Addis Ababa, Ethiopia.

[10] Belete, D.A. (2011) Road and Urban Storm Water Drainage Network Integration in Addis Ababa: Addis Ketema Sub-City. Journal of Engineering and Technology Research, 3, 217-225.

[11] Prabu, P.C. (2009) Impact of Heavy Metal Contamination of Akaki River of Ethiopia on Soil and Metal Toxicity on Cultivated Vegetable Crops. Electronic Journal of Environmental, Agricultural \& Food Chemistry, 8, 818-827.

[12] Birch, G.F., Fazeli, M.S. and Matthai, C. (2005) Efficiency of an Infiltration Basin in Removing Contaminants from Urban Stormwater. Environmental Monitoring and 
Assessment, 101, 23-38.

[13] Siriwardene, N.R., Deletic, A. and Fletcher, T.D. (2007) Clogging of Stormwater Gravel Infiltration Systems and Filters: Insights from a Laboratory Study. Water Research, 41, 1433-1440. https://doi.org/10.1016/j.watres.2006.12.040

[14] Genç-Fuhrman, H., Mikkelsen, P.S. and Ledin, A. (2007) Simultaneous Removal of As, Cd, Cr, Cu, Ni and Zn from Stormwater: Experimental Comparison of 11 Different Sorbents. Water Research, 41, 591-602. https://doi.org/10.1016/j.watres.2006.10.024

[15] Davis, A.P. (2005) Green Engineering Principles Promote Low-Impact Development. Environmental Science \& Technology, 39, 338A-344A. https://doi.org/10.1021/es053327e

[16] Wong, T.H. (2006) Australian Runoff Quality: A Guide to Water Sensitive Urban Design.

[17] Henderson, C., Greenway, M. and Phillips, I. (2007) Removal of Dissolved Nitrogen, Phosphorus and Carbon from Stormwater by Biofiltration Mesocosms. Water Science and Technology, 55, 183-191. https://doi.org/10.2166/wst.2007.108

[18] Davis, A.P., Shokouhian, M., Sharma, H. and Minami, C. (2001) Laboratory Study of Biological Retention for Urban Stormwater Management. Water Environment Research, 73, 5-14. https://doi.org/10.2175/106143001X138624

[19] Zaman, S., Yeasmin, S., Inatsu, Y., Ananchaipattana, C. and Bari, M.L. (2014) LowCost Sustainable Technologies for the Production of Clean Drinking Water-A Review. Journal of Environmental Protection, 5, 42. https://doi.org/10.4236/jep.2014.51006

[20] Nassar, A.M. and Hajjaj, K. (2013) Purification of Stormwater Using Sand Filter. Journal of Water Resource and Protection, 5, 1007. https://doi.org/10.4236/jwarp.2013.511105

[21] Rowe, D.R. and Abdel-Magid, I.M. (1995) Handbook of Wastewater Reclamation and Reuse. CRC Press, Boca Raton, Florida.

[22] Collins, M.R., Eighmy, T.T., Fenstermacher Jr., J.M. and Spanos, S.K. (1992) Removing Natural Organic Matter by Conventional Slow Sand Filtration. Journal (American Water Works Association), 80-90.

[23] Adugna, A.T., Andrianisa, H.A., Konate, Y., Ndiaye, A. and Maiga, A.H. (2015) Performance Comparison of Sand and Fine Sawdust Vermifilters in Treating Concentrated Grey Water for Urban Poor. Environmental Technology, 36, 2763-2769. https://doi.org/10.1080/09593330.2015.1046951

[24] Barbosa, A.E., Fernandes, J.N. and David, L.M. (2012) Key Issues for Sustainable Urban Stormwater Management. Water Research, 46, 6787-6798. https://doi.org/10.1016/j.watres.2012.05.029

[25] Flint, K.R. and Davis, A.P. (2007) Pollutant Mass Flushing Characterization of Highway Stormwater Runoff from an Ultra-Urban Area. Journal of Environmental Engineering, 133, 616-626. https://doi.org/10.1061/(ASCE)0733-9372(2007)133:6(616)

[26] Göbel, P., Dierkes, C. and Coldewey, W.G. (2007) Storm Water Runoff Concentration Matrix for Urban Areas. Journal of Contaminant Hydrology, 91, 26-42. https://doi.org/10.1016/j.jconhyd.2006.08.008

[27] Kim, G., Yur, J. and Kim, J. (2007) Diffuse Pollution Loading from Urban Stormwater Runoff in Daejeon City, Korea. Journal of Environmental Management, 85, 916. https://doi.org/10.1016/j.jenvman.2006.07.009

[28] Kao, C.M., Wang, J.Y., Lee, H.Y. and Wen, C.K. (2001) Application of a Con- 
structed Wetland for Non-Point Source Pollution Control. Water Science and Technology, 44, 585-590.

[29] Scholes, L., Revitt, D.M. and Ellis, J.B. (2008) A Systematic Approach for the Comparative Assessment of Stormwater Pollutant Removal Potentials. Journal of Environmental Management, 88, 467-478. https://doi.org/10.1016/j.jenvman.2007.03.003

[30] Birch, G.F., Matthai, C., Fazeli, M.S. and Suh, J.Y. (2004) Efficiency of a Constructed Wetland in removing Contaminants from Stormwater. Wetlands, 24, 459466. https://doi.org/10.1672/0277-5212(2004)024[0459:EOACWI]2.0.CO;2

[31] Aziz, H.A., Adlan, M.N. and Ariffin, K.S. (2008) Heavy Metals Removal from Water in Malaysia. Bioresource Technology, 99, 1578-1583.

https://doi.org/10.1016/j.biortech.2007.04.007

[32] Vymazal, J. (2002) The Use of Sub-Surface Constructed Wetlands for Wastewater Treatment in the Czech Republic: 10 Years Experience. Ecological Engineering, 18, 633-646. https://doi.org/10.1016/S0925-8574(02)00025-3

\section{Submit or recommend next manuscript to SCIRP and we will provide best} service for you:

Accepting pre-submission inquiries through Email, Facebook, LinkedIn, Twitter, etc. A wide selection of journals (inclusive of 9 subjects, more than 200 journals)

Providing 24-hour high-quality service

User-friendly online submission system

Fair and swift peer-review system

Efficient typesetting and proofreading procedure

Display of the result of downloads and visits, as well as the number of cited articles

Maximum dissemination of your research work

Submit your manuscript at: http://papersubmission.scirp.org/

Or contact jwarp@scirp.org 